\title{
AN EVALUATION OF PHYTOPLANKTON ASSEMBLAGE IN RELATION TO ENVIRONMENTAL VARIABLES OF NARMADA ESTUARINE REGION OF GULF OF KHAMBHAT, GUJARAT, INDIA
}

\author{
BASIL GEORGE ${ }^{1}$-NIRMAL KUMAR, J.I. ${ }^{*}$-RITA N. KUMAR ${ }^{2}$ \\ ${ }^{I}$ P.G. Department of Environmental Science and Technology, Institute of Science and \\ Technology for Advanced Studies and Research (ISTAR), \\ Vallabh Vidya Nagar, Gujarat-388120. India. \\ ${ }^{2}$ Department of Biological Science and Environmental Science, N.V. Patel College of Pure and \\ Applied Science, \\ Vallabh Vidya Nagar, Gujarat-388 120. India. \\ *Corresponding author \\ e-mail:istares2005@yahoo.com \\ (Received 10 $0^{\text {th }}$ Aug 2013; accepted 14 ${ }^{\text {th }}$ Aug 2014)
}

\begin{abstract}
A study on the relationship between physicochemical parameters and phytoplankton assemblage in Narmada estuarine region (21.40'05.19'N and 72॰34'26.90”E) of the Gulf of Khambhat, Gujarat, India was carried out from July 2009- June 2010. Principal Component Analysis with environmental variables like $\mathrm{pH}$, dissolved oxygen, salinity, ammonia, phosphate, nitrate, silicate and chlorophyll-a reveled two factors influencing variability in the water nutrient composition up to $72 \%$ during the whole study period. Canonical Correlation Analysis between environmental variables and 31 dominant taxa of phytoplankton showed the freshwater influence on phytoplankton distribution in the estuarine zone. The maximum diversity in phytoplankton assemblage was observed during the postmonsoon (November, December, January, February) and pre-monsoon (March, April, May, June) period. The same period reported a high load of inorganic nutrients at the middle and upper reaches of the estuary due to anthropogenic influence and low freshwater flow in this zone.
\end{abstract}

Keywords: estuary; environmental variable; PCA; CC; phytoplankton

\section{Introduction}

Estuaries are biologically dynamic zones with intensive exchange of matter and energy occurring between terrestrial and marine ecosystems (Prandle, 2009; Ahel, et al., 1996). Physicochemical properties play a major role in determining the density, diversity and occurrence of phytoplankton in marine and freshwater ecosystem. The quality and quantity of phytoplankton and their seasonal patterns have been successfully implicated in the quality of water and its capacity to sustain heterotrophic communities (White et al., 2004). Dynamic changes in; $\mathrm{pH}$, trace metal speciation, concentrations of dissolved gases like oxygen, carbon dioxide, methane, inorganic nutrients (nitrate, phosphate, silicate) and organic compounds such as amino acids, organo-sulfur compounds are all closely associated with fluctuations in phytoplankton composition (George et al., 2012). Trophic linkages also exist, between phytoplankton who are primary producers and populations of consumer organisms including zooplankton, benthic invertebrates and fish. The phytoplankton communities are also useful indicators of estuarine water quality (Paerl et al., 2007). 
The variation of phytoplankton succession is strongly linked to meteorological and water stratification mixing processes in a tropical estuary (Devassy and Goes, 1988). The complex dynamism in physico-chemical characteristics of coastal waters is related to riverine flow, up welling, atmospheric deposition, vertical mixing and other anthropogenic sources. The coastal Gulf of Khambhat, Gujarat State, India, is a unique marine environment in the tropical belt with marked continental influence due to the drainage by 16 major and minor rivers in to the Gulf. In the present study involving one such riverine system, the Narmada estuarine region, hydro-chemical variables were evaluated to determine their role in phytoplankton distribution using various statistical methods.

\section{Materials and Methods}

Narmada estuarine region is located at geographical coordinates $21 \circ 40$ '05.19' $\mathrm{N}$, 72॰34'26.90'E. Three study sites in this region were selected Zadeshwar, Bhadbhut and Ambata (10-15 km between each sites) on the basis of upcoming industrial set ups and anthropogenic pressure at these regions (Figure 1).

Surface water samples were drawn at monthly intervals during the period from July 2009 to June 2010 at high tide. For nutrient analysis, water samples were collected in 1 $\mathrm{L}$ clean polythene bottles and kept in an ice box at $4^{\circ} \mathrm{C}$ and transported immediately to the laboratory. Physico-chemical parameters such as $\mathrm{pH}$, dissolved oxygen (DO), phosphate $\left(\mathrm{PO}_{4}-\mathrm{P}\right)$, nitrate $\left(\mathrm{NO}_{3}-\mathrm{N}\right)$, ammonia $\left(\mathrm{NH}_{4}\right)$ and silicate $\left(\mathrm{SiO}_{4}-\mathrm{Si}\right)$ were measured according to the standard procedures (APHA, 1998; Strickland and Parsons, 1979). The data quality was ensured through careful standardization, procedural blank measurements, and using spike and duplicate samples. Measurements of in situ temperature $\left({ }^{\circ} \mathrm{C}\right)$ and salinity (ppt) were made using probes, while DO was measured using Winkler's method. The chlorophyll-a estimation was carried out in a spectrophotometer after filtering the samples using glass fiber filter papers and extraction in $90 \%$ acetone (Maiti, 2003).

Plankton samples were collected by filtering 10 liters of water through planktonic net of $20 \mu$ mesh size and were preserved in $4 \%$ formalin for future use. Plankton identification was carried out with help of literatures and books (Desikachary, 1959; Newell and Newell, 1977; Thomas, 1997). The enumerations of phytoplankton were carried out with the aid of light microscope by Lackey's drop method (Lackey, 1938).

\section{Results and Discussion}

Principal component analysis (PCA) is one of the best statistical techniques for extracting relationships among a set of variables. Principal component analysis aims to transform the observed variables to a new set of variables of principal components (PC) which are arranged in decreasing order of importance. . Principal components are the linear combinations of original variables and are the eigenvectors (Reingner, 2008). The data obtained from the laboratory analysis were used as variable inputs for principal components analysis (PCA), for water samples described using the SPSS 17 package. Prior to the analysis, the data was standardized by transforming all data to have a zero mean and a unit standard deviation $\left(\mathrm{X}_{\mathrm{i}}-\mu\right) / \delta, \mu$ and $\delta$ are standard deviations of $\mathrm{X}_{\mathrm{i}}$ 's. Rotation of data will ensure that the variability explained is more or less evenly distributed between the factors. From the standardized covariance or correlation matrix 
of the data, the initial factor solution was extracted by the multivariate principal components extraction, then a number of PC were selected only those with eigenvalues $>1.0$.

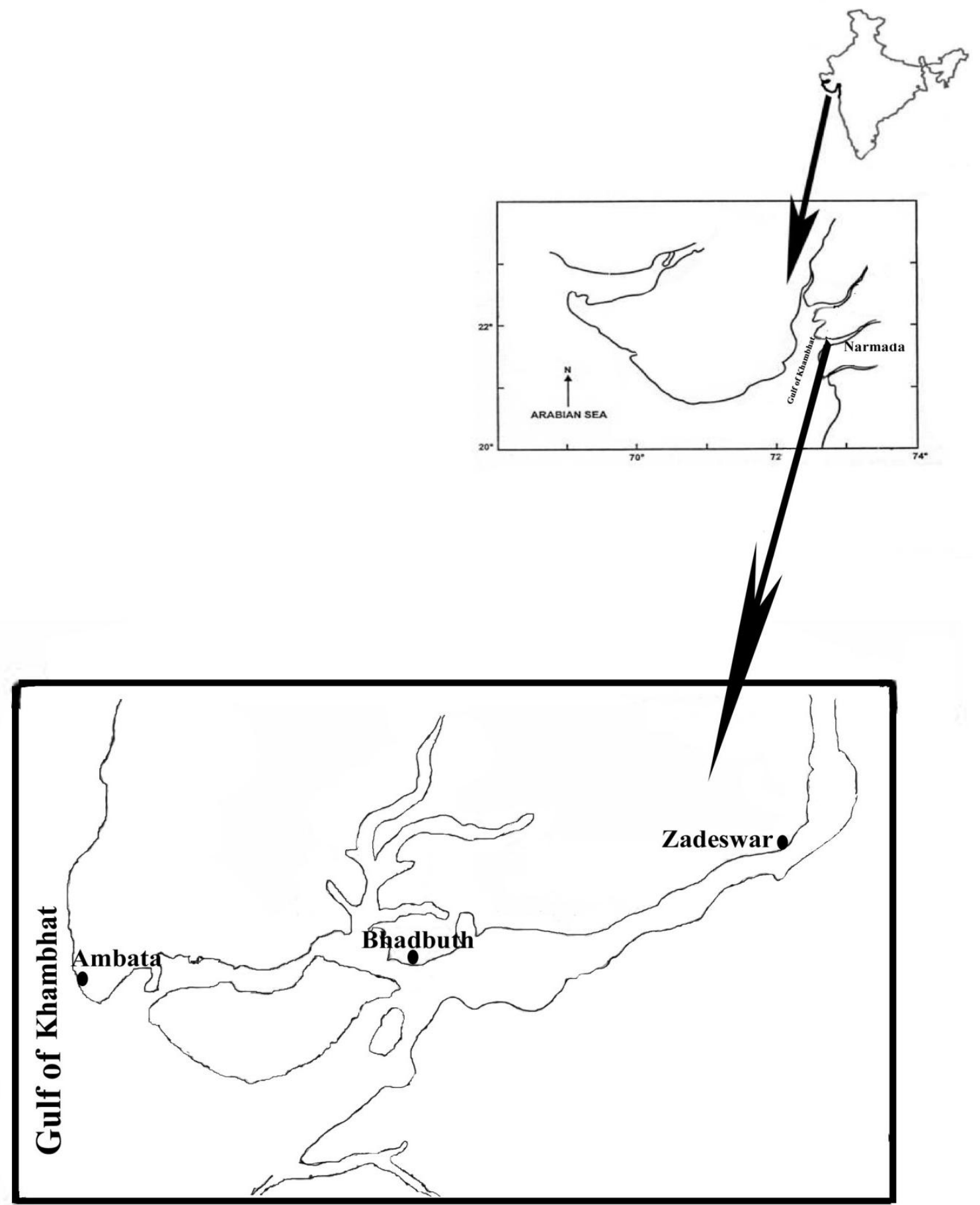

Figure 1. Selected study sites on Narmada estuarine zone. 
Initial eigenvalues, percentage of variance and cumulative percentage obtained through principal component analysis is represented in table 1. Eigenvalues above 1.0 account for the first two axis and represent more than $76 \%$ of the variance. Components loading, which measure the degree of closeness between the variables and the PC, the largest loading either positive or negative, suggest the meaning of the dimensions; positive loading indicates that the contribution of the variables increases with the increasing loading in dimension and negative loading indicates a decrease. Temperature variation in Narmada estuarine region followed a similar trend observed in other tropical regions (Newall et al., 2011).

Table 1.Total Variance Explained Narmada estuary

\begin{tabular}{|c|c|c|c|c|c|c|}
\hline \multirow[b]{2}{*}{ Component } & \multicolumn{3}{|c|}{ Initial Eigenvalues } & \multicolumn{3}{|c|}{ Rotation Sums of Squared Loadings } \\
\hline & Total & $\begin{array}{c}\% \text { of } \\
\text { Variance }\end{array}$ & $\begin{array}{c}\text { Cumulative } \\
\%\end{array}$ & Total & $\begin{array}{c}\% \text { of } \\
\text { Variance }\end{array}$ & $\begin{array}{c}\text { Cumulative } \\
\%\end{array}$ \\
\hline 1 & 5.582 & 62.021 & 62.021 & 4.658 & 51.754 & 51.754 \\
\hline 2 & 1.309 & 14.541 & 76.562 & 2.233 & 24.808 & 76.562 \\
\hline 3 & .892 & 9.915 & 86.478 & & & \\
\hline 4 & .746 & 8.293 & 94.771 & & & \\
\hline 5 & .155 & 1.722 & 96.492 & & & \\
\hline 6 & .128 & 1.423 & 97.915 & & & \\
\hline 7 & .099 & 1.096 & 99.012 & & & \\
\hline 8 & .054 & .595 & 99.607 & & & \\
\hline 9 & .035 & .393 & 100.000 & & & \\
\hline
\end{tabular}

PC1 accounts for $62.02 \%$ of the total variance, which is due to strong positive load of silicates (0.950), chlorophyll- $a(0.870)$ and nitrate (0.794), ammonia (0.801), dissolved oxygen (0.880) and a strong negative load of salinity (-0.842) and $\mathrm{pH}(-0.820)$. There is a significant positive correlation $(\mathrm{p} \leq 0.05)$ of $\mathrm{pH}$ with salinity $(r=0.81)$, where as silicates and chlorophyll showed a positive correlation with DO $(r=0.75$ and 0.76 respectively). Ammonia showed a significant positive correlation with silicate $(r=0.84)$ and chlorophyll- $a(r=0.85)$ and silicate also found to be positively correlated with chlorophyll-a $((r=0.87)$. Silicate $(r=-0.86)$ and chlorophyll-a $(r=-0.65)$ showed a significant negative correlation with salinity (Table 2$)$.

The highest value of ammonia is associated with freshwater inflow, and positive correlation with silicate indicates the freshwater origin of nutrients (Martin et al., 2008). The highest amount was reported in the upper reaches during the post monsoon period. In an estuarine environment, the primary productivity depends upon phytoplankton, which along with macrophytes contributes more than $90 \%$ of the total estuarine primary productivity (Bally et al., 1985). Thus, chl- $a$, which constitutes the chief photosynthetic pigment of phytoplankton, is an index that indicates the primary production potential of that system's biodiversity, biomass and carrying capacity (Nirmal, et al, 2009). Chlorophyll- $a(3.5 \mathrm{mg} / \mathrm{L}-8.9 \mathrm{mg} / \mathrm{L})$ having a significant positive correlation with DO and inorganic nutrients were observed to be high during the post monsoon period. The range of inorganic nutrient concentration during the study period is represented as box plot in Figure 2. The concentration of nitrate $(0.489 \mathrm{mg} / \mathrm{L}-1.84$ 
$\mathrm{mg} / \mathrm{L})$ and phosphate $(0.058 \mathrm{mg} / \mathrm{L}-0.377 \mathrm{mg} / \mathrm{L})$ were observed to be high at the middle reaches, mostly during the post- monsoon and pre-monsoon because of surface run off, increased pollution load, low freshwater inflow and tidal influence (Pradhan et al., 2009).

Table 2. Correlation between physicochemical parameters of Narmada estuary $(\mathrm{P}<0.05)$.

\begin{tabular}{|c|c|c|c|c|c|c|c|c|c|}
\hline & Temp & $\mathrm{pH}$ & DO & Salinity & Ammonia & Phosphate & Nitrate & Silicate & Chlorophyll \\
\hline Temperature & 1.000 & & & & & & & & \\
\hline $\mathrm{pH}$ & .470 & 1.000 & & & & & & & \\
\hline DO & -.706 & -.674 & 1.000 & & & & & & \\
\hline Salinity & .238 & .815 & -.603 & 1.000 & & & & & \\
\hline Ammonia & -.253 & -.581 & .729 & -.687 & 1.000 & & & & \\
\hline Phosphate & -.302 & -.067 & .197 & -.164 & .015 & 1.000 & & & \\
\hline Nitrate & -.620 & -.696 & .638 & -.658 & .342 & .504 & 1.000 & & \\
\hline Silicate & -.431 & -.739 & .754 & -.860 & .841 & .325 & .692 & 1.000 & \\
\hline Chlorophyll & -.409 & -.519 & .765 & -.654 & .853 & .422 & .536 & .871 & 1.000 \\
\hline
\end{tabular}

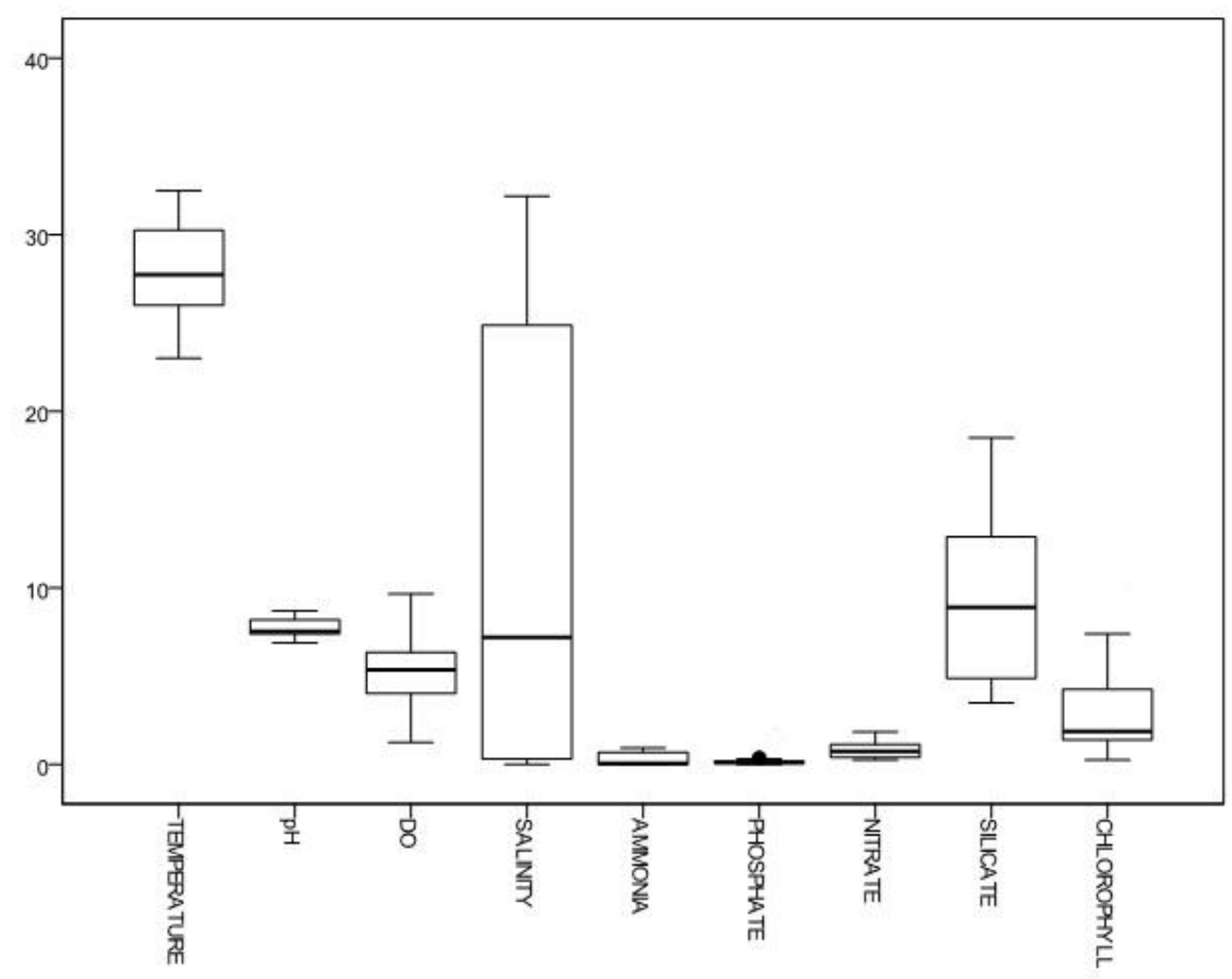

Figure 2. Box plot showing variation of hydro-chemical parameters. All parameters are in $\mathrm{mg} / \mathrm{L}$ except temperature and $\mathrm{pH}$.

PC2 explains $14.5 \%$ of the total variance with strong positive loading of $\mathrm{NO}_{3}-\mathrm{N}$ $(0.74)$ (Table 3). There is a strong positive correlation $(\mathrm{p}<0.05)$ of nitrate with silicate $(r$ 
$=0.69)$ and negative correlation with temperature $(r=0.62), \mathrm{pH}(r=0.69)$ and salinity $(r=0.44)$. $\mathrm{pH}$ showed a clear variation from fresh water receiving sites to the highly saline area. Comparatively, the strong negative correlation between salinity and $\mathrm{NO}_{3}-\mathrm{N}$ $(r=-0.63)$ indicates the addition of $\mathrm{NO}_{3}-\mathrm{N}$ from the riverine freshwater direction. The amount of nitrates $(0.489$ to $1.84 \mathrm{mg} / \mathrm{L})$ was observed higher in post-monsoon season followed by pre-monsoon season in the upper and middle reaches. The high amount of inorganic nutrients observed at upper reaches may be contributed by freshwater inflow (Satpathy et al., 2009).

Table 3. Principle component loadings in Narmada estuary

\begin{tabular}{|l|c|c|}
\hline & \multicolumn{2}{|c|}{ Component } \\
\hline & 1 & 2 \\
\hline Temperature & -.606 & -.499 \\
\hline PH & -.820 & .145 \\
\hline DO & .880 & .016 \\
\hline Salinity & -.842 & .266 \\
\hline Ammonia & .801 & -.475 \\
\hline Phosphate & .357 & .742 \\
\hline Nitrate & .794 & .411 \\
\hline Silicate & .950 & -.133 \\
\hline Chlorophyll a & .870 & -.067 \\
\hline
\end{tabular}

Relationships between phytoplankton species composition and environmental factors were calculated by Canonical Correlation Analysis (Ariyadej, 2004) using Statistica 9 software (Statsoft). CCA is a direct ordination that selects the combination of environmental variables that maximize the dispersion of the scores of species (Palmer, 2006). Results of environmental variables are shown by lines radiating from the center of the graph along with the points for samples. The line representing environmental variable indicates the direction of maximum change of that variable across the diagram. The position of the species point represents the environmental preference of the species.

In Zadeshwar, a total of 35 species and 16 environmental variables (which may have contributed to phytoplankton distribution) were selected for CCA analysis. Eigenvalue of axis $1(\lambda=0.2027), 2(\lambda=0.1694), 3(\lambda=0.1065)$ and $4(\lambda=0.087)$ explained $72.88 \%$ of the relation between species and environmental data. Species having significant correlation (>0.5 to <-0.5) with axis were marked in bold. The length of environmental arrows and their orientation on the biplot indicates their relative importance to each axis. Environmental arrows represent a gradient where the mean value is located at the origin and the arrow points in the direction of its increase (Fig.3). In CCA analysis, the first axis can be interpreted as the marine water influence and the main contributors include $\mathrm{pH}$, salinity, chloride, chlorinity, alkalinity, sodium, potassium, sulphate and EC. Chlorophyll-a, phosphate, DO, temperature and silicate concentration were significantly correlated to each other in one side of axis 1 whereas silicate and nitrate shows a significant correlation with axis 1 on another side (Table 4).

Oscillatoria accuminata, Anabena anomala, Closterium gracile, Cladophora glomerata showed positive correlation with axis 1 which signify the effect of nitrate and silicate on its distribution. Temperature was found to have a positive relation with 
Scenedesmus quadricaudata. Cladophora glomerata. Phacus accuminatus, Navicula amphirhynclius, Gymnodium, Merismopedium punctata, Pinnularia elongatum showed a positive correlation with $\mathrm{pH}$, salinity, chloride, chlorinity, alkalinity, sodium, potassium, sulphate and EC which indicate the significant role of these parameters in phytoplankton distribution. The effect of chemical factors, especially salinity and nutrient composition on phytoplankton distribution in Mahanadi estuary of India was studied by Naik et al. (2009) and they have reported higher phytoplankton count, chlorophyll-a concentration and nutrients during post-monsoon season which corroborated with our studies. Moreover, Oscillatoria curviceps, O.subbrevis and Nostoc sp. showed a positive correlation with chlorophyll-a and phosphate. While Nitzschia plea, Merismopedium glauca, Anabena anomala, Pinnularia elongatum and Ankistrodesmus hantzschii showed a positive correlation with silicate and nitrate. The values of each canonical variable of phytoplankton with the axis and the range of occurrence along with abbreviation are given in Table 5.

Table 4. Correlation of environmental variables with axes in Zadeshwar

\begin{tabular}{lcccc}
\hline Variables & $\begin{array}{c}\text { CV 1 } \\
(\boldsymbol{\lambda}=\mathbf{0 . 2 0 2 7 )}\end{array}$ & $\begin{array}{c}\text { CV 2 } \\
(\boldsymbol{\lambda}=\mathbf{0 . 1 6 9 4 )}\end{array}$ & $\begin{array}{c}\text { CV 3 } \\
(\boldsymbol{\lambda}=\mathbf{0 .} 1065)\end{array}$ & $\begin{array}{c}\text { CV 4 } \\
(\boldsymbol{\lambda}=\mathbf{0 . 0} 08)\end{array}$ \\
\hline Temperature & $\mathbf{- 0 . 5 0 0}$ & $\mathbf{0 . 7 4 1}$ & -0.006 & 0.074 \\
pH & $\mathbf{- 0 . 5 6 3}$ & 0.309 & -0.121 & 0.182 \\
DO & -0.156 & $\mathbf{- 0 . 7 4 6}$ & 0.095 & -0.142 \\
TS & 0.175 & 0.378 & -0.024 & 0.031 \\
Salinity & $\mathbf{- 0 . 6 1 2}$ & $\mathbf{0 . 4 5 0}$ & -0.365 & 0.154 \\
Chloride & $\mathbf{- 0 . 6 0 1}$ & $\mathbf{0 . 4 5 7}$ & -0.359 & 0.149 \\
Alkalinity & $\mathbf{- 0 . 7 0 3}$ & 0.199 & $\mathbf{- 0 . 4 0 3}$ & 0.231 \\
Sodium & $\mathbf{- 0 . 6 2 7}$ & 0.295 & -0.315 & 0.042 \\
Potassium & $\mathbf{- 0 . 6 5 1}$ & $\mathbf{0 . 4 2 1}$ & -0.247 & 0.229 \\
Ammonia & -0.166 & 0.049 & 0.176 & 0.273 \\
Phosphate & $\mathbf{- 0 . 5 3 8}$ & -0.349 & -0.265 & 0.225 \\
Nitrate & 0.011 & $\mathbf{- 0 . 4 5 8}$ & 0.212 & -0.256 \\
Sulphate & $\mathbf{- 0 . 5 8 3}$ & 0.158 & -0.324 & 0.362 \\
Silicate & 0.064 & $\mathbf{- 0 . 8 0 8}$ & 0.094 & 0.111 \\
Chlorophyll-a & -0.152 & $\mathbf{- 0 . 7 1 5}$ & -0.254 & 0.105 \\
EC & $\mathbf{- 0 . 5 3 4}$ & 0.237 & -0.124 & 0.226 \\
\% of Total & & & & \\
variation & $\mathbf{2 6 . 1 3}$ & $\mathbf{2 1 . 8 3}$ & $\mathbf{1 3 . 7 3}$ & $\mathbf{1 1 . 1 9}$ \\
\hline
\end{tabular}

In Bhadbhut, a total of 31 species were reported and analyzed with 16 hydrochemical parameters for CCA analysis. Eigenvalue of axis $1(\lambda=0.187), 2(\lambda=0.173), 3$ $(\lambda=0.102)$ and $4(\lambda=0.064)$ explained $73.32 \%$ of the relation between species and environmental data (Table 6). Chlorophyll- $a$ and silicate concentration showed a negative correlation with chloride, alkalinity, sodium, $\mathrm{pH}$, potassium, sulphate and temperature. Phosphate, ammonia and nitrate showed positive correlation with axis 2 . Nitzschia obtusa, Chroococcus gigantium, Pediastrum simplex, Amphiprora alata, Oscillatoria subbrevis, Navicula amphirhynclius and Fragilaria crotonensis did not 
explain much variation in distribution with change in physicochemical properties (Fig. 4). Navicula viridis, Amphora ovalis and Chaetoceros tenuissimus illustated close relationship with nitrate and phosphate. Chlorella pyrenoidosa, Ankistrodesmus hantzschii, Ankistrodesmus flactus, Ceratium, Microcystis aeruginosa and Navicula amphirhynclius found to have close relationship between DO, chlorophyll- $a$ and silicate. Panigrahi et al. (2009) also reported the effect of these nutrients in phytoplankton distribution from their studies on brackish water ecosystem (Chilika Lagoon, India). Closterium acerosum and Pleurosigma elongetum found to be correlated with potassium, sulphate and temperature variation in the estuary. The correlation of phytoplankton with axis is given in the (Table 7) and the values having significant correlation are marked in bold.

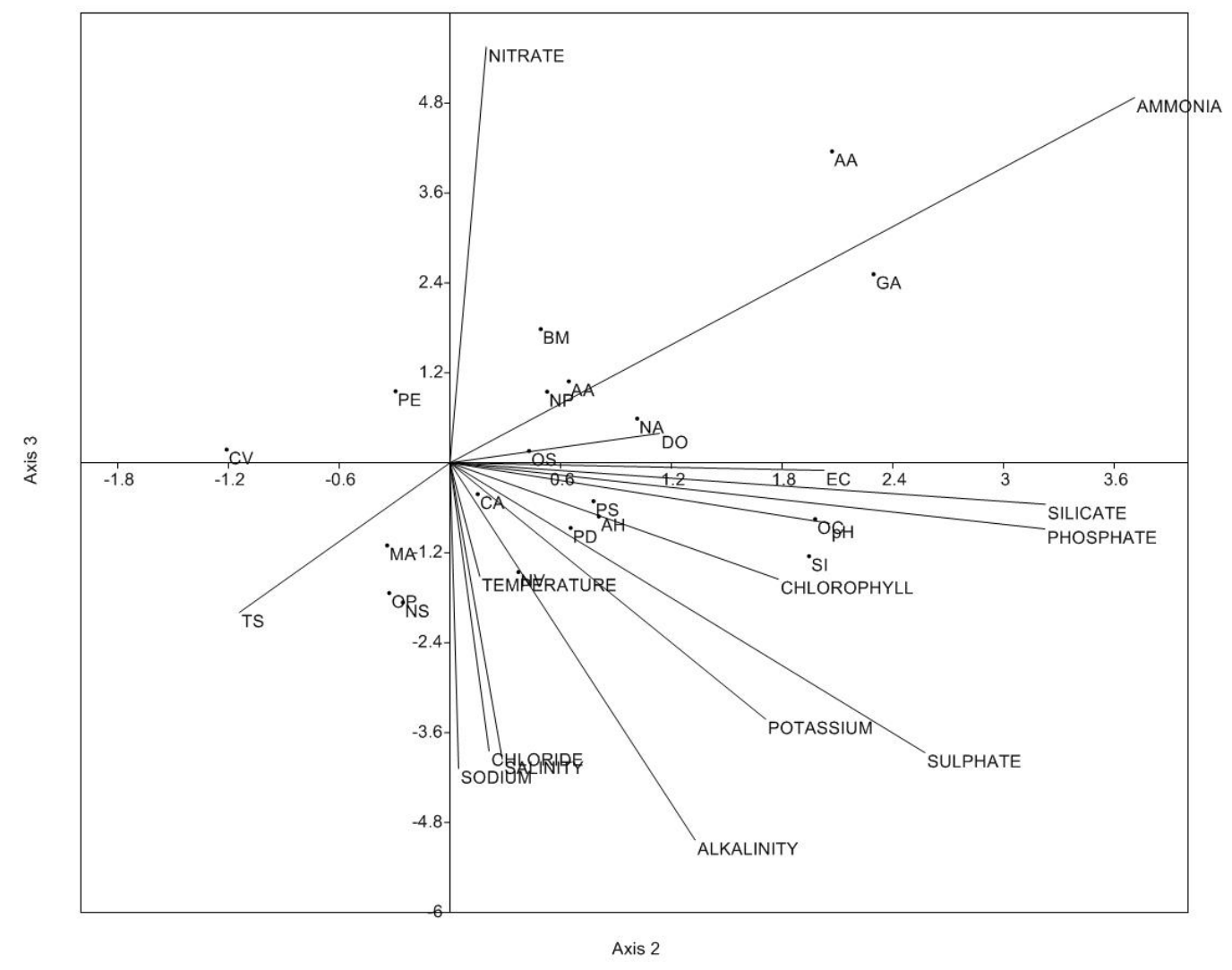

Figure 3. CCA plot showing relationship between environmental variables and phytoplankton of Zadeshwar.

Table 5. List of phytoplankton taxa included in the canonical correlation analysis of Zadeshwar

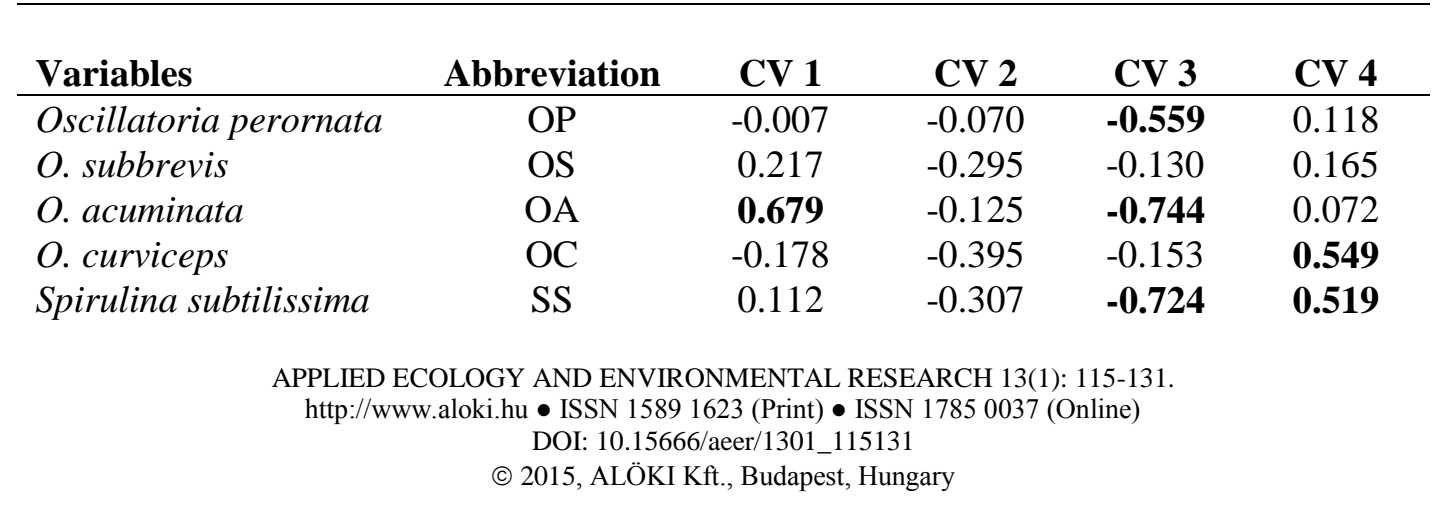




$$
-123-
$$

\begin{tabular}{|c|c|c|c|c|c|}
\hline Microcystis aeruginosa & MA & -0.137 & 0.118 & -0.096 & -0.065 \\
\hline Anaebena anomala & AA & 0.768 & -0.082 & 0.326 & 0.310 \\
\hline Merismopedium glauca & MG & 0.100 & -0.261 & 0.073 & 0.255 \\
\hline M. punctata & MP & 0.021 & -0.273 & -1.211 & 0.443 \\
\hline Nostoc $s p$ & NS & -0.061 & -0.436 & -0.318 & -0.067 \\
\hline \multicolumn{6}{|l|}{ Ankistrodesmus } \\
\hline hantzschii & $\mathrm{AH}$ & -0.092 & -0.263 & 0.035 & 0.195 \\
\hline Clorella vulgaris & $\mathrm{CV}$ & -0.118 & 0.309 & -0.113 & -0.332 \\
\hline Closterium acerosum & $\mathrm{CA}$ & 0.218 & -0.635 & -0.200 & 0.031 \\
\hline C. gracile & $\mathrm{CG}$ & 0.699 & 0.390 & -0.572 & 0.285 \\
\hline Cladophora glomerata & CGL & 0.662 & 0.964 & 0.405 & 0.492 \\
\hline \multicolumn{6}{|l|}{ Scenedesmus } \\
\hline quadricauda & SQ & 0.477 & 0.890 & 0.227 & 0.120 \\
\hline Spirogyra indica & SI & -0.481 & 0.774 & 0.038 & 0.796 \\
\hline Pediastrum simplex & PS & 0.014 & -0.276 & -0.045 & 0.262 \\
\hline P. duplex & PD & 0.109 & -0.286 & -0.284 & 0.337 \\
\hline Amphiprora alata & AA & -0.157 & -0.364 & 1.461 & -0.193 \\
\hline Biddulphia mobiliensis & $\mathrm{BM}$ & 0.192 & 0.008 & 0.528 & -0.044 \\
\hline \multicolumn{6}{|l|}{ Coscinodiscus } \\
\hline marginatus & $\mathrm{CM}$ & -0.176 & -0.800 & 0.268 & -0.507 \\
\hline Cymbellacistula & $\mathrm{CC}$ & 0.039 & -0.397 & -0.337 & 0.383 \\
\hline C. tumida & CT & -0.226 & -0.573 & 0.862 & 0.142 \\
\hline Gyrosigma acuminatum & GA & -0.110 & -0.481 & 1.003 & 0.121 \\
\hline G. scalproides & GS & -0.187 & -0.420 & 0.931 & 0.256 \\
\hline \multicolumn{6}{|l|}{ Navicula } \\
\hline amphirhynclius & NA & -0.340 & 0.229 & 0.142 & 0.208 \\
\hline$N$. viridis & NV & -0.057 & -0.596 & -0.248 & 0.039 \\
\hline Pinnularia elongetum & PE & 0.402 & -0.331 & 0.041 & -0.128 \\
\hline Nitzschia palea & NP & -0.158 & -0.163 & 0.193 & -0.044 \\
\hline Euglena gracilis & EG & -0.573 & 0.534 & -0.724 & 0.955 \\
\hline E. ehrenbergii & $\mathrm{EE}$ & 0.106 & -0.933 & -0.015 & 0.539 \\
\hline Phacus acuminatus & PA & -0.521 & 0.265 & 0.230 & 0.372 \\
\hline Peridinium & $\mathrm{Pe}$ & 0.399 & 0.390 & -0.572 & 0.285 \\
\hline Gymnodium & Gy & -0.741 & 0.579 & 0.313 & -0.243 \\
\hline
\end{tabular}

Table 6. Correlation of environmental variables with axes of Bhadbhut

\begin{tabular}{|c|c|c|c|c|}
\hline Variables & $\begin{array}{l}\text { CV 1 } \\
(\lambda=\mathbf{0 .} 187)\end{array}$ & $\begin{array}{l}\text { CV } 2 \\
(\lambda=0.173)\end{array}$ & $\begin{array}{l}\text { CV 3 } \\
(\boldsymbol{\lambda}=\mathbf{0 .} 102)\end{array}$ & $\begin{array}{l}\text { CV } 4 \\
(\lambda=\mathbf{0 . 0 6 4 )}\end{array}$ \\
\hline Temperature & 0.57 & 0.17 & 0.23 & -0.62 \\
\hline $\mathrm{pH}$ & 0.40 & 0.52 & 0.31 & -0.29 \\
\hline DO & -0.39 & -0.23 & -0.14 & 0.65 \\
\hline $\mathrm{TS}$ & -0.44 & 0.58 & 0.10 & 0.17 \\
\hline Salinity & 0.05 & 0.60 & 0.31 & -0.33 \\
\hline Chloride & 0.05 & 0.60 & 0.31 & -0.33 \\
\hline Alkalinity & 0.14 & 0.51 & 0.63 & -0.11 \\
\hline Sodium & 0.15 & 0.29 & 0.39 & -0.40 \\
\hline Potassium & 0.44 & 0.77 & 0.14 & -0.11 \\
\hline $\begin{array}{l}\text { APPLIF } \\
\text { http: }\end{array}$ & $\begin{array}{r}\text { OGY AND ENV } \\
\text { oki.hu } \bullet \text { ISSN } 15 \\
\text { DOI: } 10.15 \\
\text { (c) } 2015 \text {, ALÖF }\end{array}$ & $\begin{array}{l}\text { RONMENTAL R } \\
91623 \text { (Print) } \\
66 / \text { aeer/1301_11 } \\
\text { I Kft., Budapest, }\end{array}$ & $\begin{array}{l}\text { ESEARCH 13(1): } \\
\text { SSN } 17850037(\mathrm{O} \\
131 \\
\text { Iungary }\end{array}$ & $\begin{array}{l}5-131 . \\
\text { ne) }\end{array}$ \\
\hline
\end{tabular}




$$
-124 \text { - }
$$

\begin{tabular}{lcccc} 
Ammonia & 0.47 & $\mathbf{0 . 4 9}$ & $\mathbf{0 . 6 2}$ & 0.31 \\
Phosphate & -0.39 & 0.45 & 0.05 & 0.25 \\
Nitrate & -0.23 & $\mathbf{0 . 5 7}$ & 0.04 & 0.56 \\
Sulphate & 0.44 & $\mathbf{0 . 5 0}$ & 0.41 & -0.40 \\
Silicate & $\mathbf{- 0 . 7 8}$ & 0.00 & $\mathbf{- 0 . 5 7}$ & -0.08 \\
Chlorophyll-a & $\mathbf{- 0 . 6 2}$ & 0.22 & 0.14 & 0.42 \\
EC & 0.11 & $\mathbf{0 . 5 8}$ & 0.44 & 0.07 \\
\% Total & & & & \\
Variation & $\mathbf{2 6 . 0 7}$ & $\mathbf{2 4 . 1 3}$ & $\mathbf{1 4 . 2 5}$ & $\mathbf{8 . 8 7}$ \\
\hline
\end{tabular}

Table 7. List of phytoplankton taxa included in the canonical correlation analysis of Bhadbhut

\begin{tabular}{|c|c|c|c|c|c|}
\hline Variables & Abbreviation & CV 1 & CV 2 & CV 3 & CV 4 \\
\hline Oscillatoria perornata & $\mathrm{OP}$ & 0.58 & -0.21 & 0.03 & 0.29 \\
\hline O. subbrevis & OS & -0.03 & -0.02 & 0.51 & -0.66 \\
\hline Microcystis aeruginosa & MA & 0.17 & -0.18 & -0.19 & -0.03 \\
\hline Anaebena circularis & $\mathrm{AC}$ & -0.58 & -0.65 & 0.18 & -0.42 \\
\hline Merismopedium glauca & MG & -0.56 & -0.16 & -0.65 & -0.39 \\
\hline Ankistrodesmus hantzschii & $\mathrm{AH}$ & -0.79 & -0.27 & 0.14 & -0.01 \\
\hline A. flactus & $\mathrm{AF}$ & -0.63 & 0.29 & 0.75 & 0.36 \\
\hline Chlorella pyrenoidosa & $\mathrm{CP}$ & -0.82 & 0.18 & 0.02 & 0.25 \\
\hline Closterium acerosum & CA & 0.88 & 0.27 & -0.17 & 0.82 \\
\hline Pediastrum simplex & PS & -0.04 & 0.23 & 0.69 & -0.15 \\
\hline Spirogyra indica & SI & 0.19 & -0.41 & 0.14 & -0.32 \\
\hline Amphiprora alata & AA & 0.02 & 0.23 & -1.09 & -0.13 \\
\hline Amphora ovalis & $\mathrm{AO}$ & -0.26 & 0.21 & -0.01 & 0.45 \\
\hline Biddulphia mobiliensis & $\mathrm{BM}$ & 0.13 & -0.22 & -0.19 & -0.22 \\
\hline Chaetoceros tenuissimus & $\mathrm{CT}$ & -0.30 & 0.48 & -0.35 & -0.29 \\
\hline Chroococcus gigantium & CG & -0.09 & 0.18 & -0.17 & 0.44 \\
\hline Coscinodiscus marginatus & $\mathrm{CM}$ & -0.62 & 0.21 & -1.15 & -0.46 \\
\hline Cymbella cistula & $\mathrm{CC}$ & 0.20 & 0.35 & -0.70 & -0.18 \\
\hline Fragilaria crotonensis & FC & 0.02 & -0.32 & 0.04 & -0.16 \\
\hline Gyrosigma acuminatum & GA & 0.25 & -1.02 & -0.76 & -0.02 \\
\hline G. scalproides & GS & 0.72 & -3.31 & 0.33 & 0.03 \\
\hline Navicula amphirhynclius & NA & -0.42 & -0.22 & 0.02 & 0.22 \\
\hline N. sphaerophora & NS & -0.03 & 0.27 & 0.01 & 0.33 \\
\hline$N$. viridis & NV & -0.32 & 0.28 & -0.07 & 0.10 \\
\hline Nitzschia amphibia & NA & 0.04 & -0.24 & 0.57 & -0.26 \\
\hline N. obtusa & NO & -0.03 & 0.27 & 0.01 & 0.33 \\
\hline Surirella nervosa & SN & -0.55 & 0.18 & -0.68 & -0.69 \\
\hline Pleurosigma elongetum & PE & 0.56 & 0.42 & 0.12 & -0.06 \\
\hline Euglena gracilis & $\mathrm{EG}$ & 0.72 & -0.31 & 0.33 & 0.03 \\
\hline Ceratium & $\mathrm{Ce}$ & -0.66 & 0.18 & -0.78 & -0.31 \\
\hline Gymnodium & Gy & -0.37 & -0.92 & 0.60 & 0.53 \\
\hline
\end{tabular}




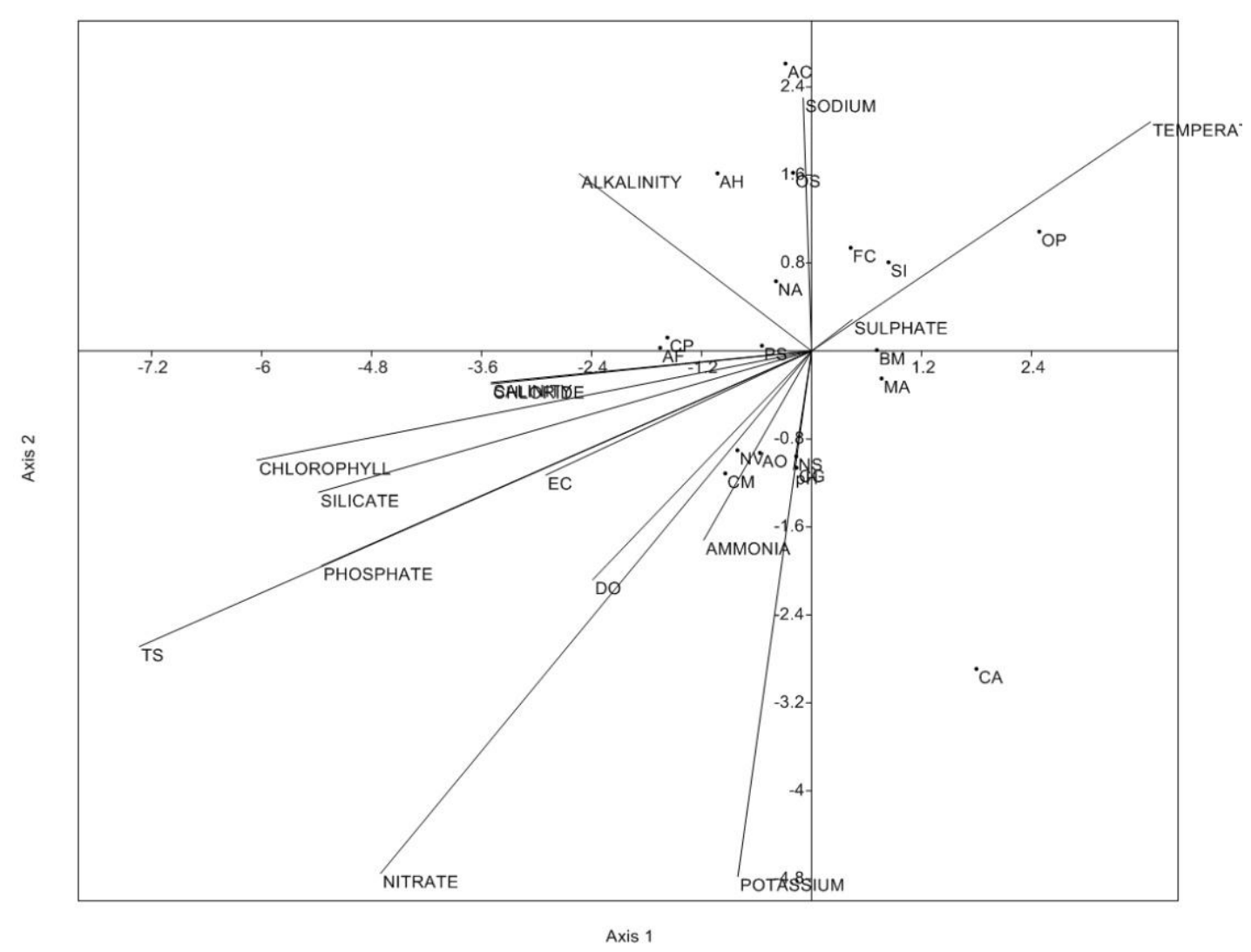

Figure 4. CCA plot showing relationship between environmental variables and phytoplankton of Bhadbhut.

Ambata site reported the least number of phytoplankton (26 species) dominated by Bacillariophycean members. Eigenvalue of axis $1(\lambda=0.361), 2(\lambda=0.271), 3(\lambda=0.234)$ and $4(\lambda=0.177)$ explained $70.44 \%$ of the relation between species and environmental data (Table 8). DO, nitrate, ammonia, chlorophyll-a, and silicate found to be correlated with each other and showed a negative correlation with potassium, temperature and salinity. These indicated the freshwater and marine water source of these nutrients in to the estuarine environment. Peridinium, Ceratium, Amphora elliptica, Surirella nervosa and Gymnodium showed a positive correlation with potassium and temperature. Thalassionema nitzschioides, Chaetoceros tenuissimus, Merismopedium punctata, Fragilaria oceanic and Leptocylindrus danicus found to be closely associated with concentration of nitrate, chlorophyll, ammonia and silicate (Fig. 5).Correlation of environmental variables with phytoplankton species were given in Table 9. Similar results were also obtained from shallow coastal station of Bay of Bengal by Choudhury and Pal, (2010) in which they observed prominent effect of temperature, $\mathrm{pH}$, dissolved oxygen, salinity and nutrient contents-including nitrate, phosphate and silicate on Bacillariophycean distribution. 


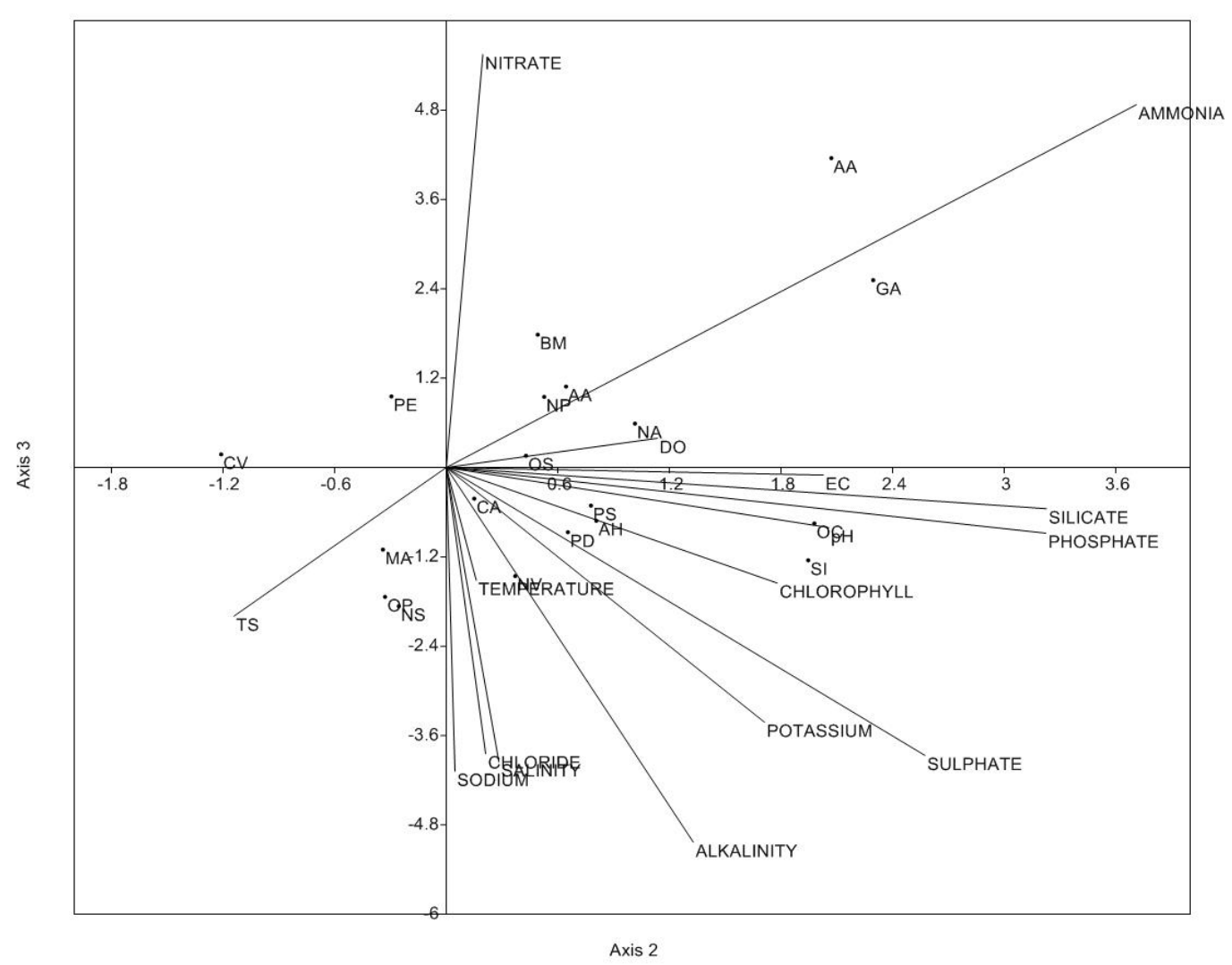

Figure 5.CCA plot showing relationship between environmental variables and phytoplankton of Ambata.

Table 8. Correlation of environmental variables with axes in Ambata

\begin{tabular}{lcccc}
\hline Variables & $\begin{array}{c}\mathbf{C V ~} \\
(\boldsymbol{\lambda}=\mathbf{0 .} .361)\end{array}$ & $\begin{array}{c}\mathbf{C V ~ 2} \\
(\boldsymbol{\lambda}=\mathbf{0 . 2} 21)\end{array}$ & $\begin{array}{c}\mathbf{C V ~ 3} \\
(\boldsymbol{\lambda}=\mathbf{0 . 2} 24)\end{array}$ & $\begin{array}{c}\mathbf{C V ~ 4} \\
(\boldsymbol{\lambda}=\mathbf{0 . ~ 1 7 6 )}\end{array}$ \\
\hline Temperature & 0.11 & 0.42 & 0.18 & -0.32 \\
pH & -0.41 & 0.68 & -0.14 & -0.40 \\
DO & -0.07 & -0.49 & -0.38 & 0.29 \\
TS & -0.49 & 0.51 & -0.34 & 0.05 \\
Salinity & -0.16 & 0.57 & -0.49 & -0.42 \\
Chloride & -0.16 & 0.57 & -0.49 & -0.42 \\
Alkalinity & -0.17 & 0.56 & -0.05 & -0.25 \\
Sodium & -0.66 & 0.47 & -0.20 & -0.36 \\
Potassium & -0.05 & 0.65 & -0.01 & -0.38 \\
Ammonia & -0.16 & -0.62 & -0.18 & -0.21 \\
Phosphate & -0.45 & 0.16 & -0.42 & -0.30 \\
Nitrate & -0.48 & -0.35 & -0.13 & 0.24 \\
Sulphate & -0.18 & 0.53 & -0.32 & -0.22
\end{tabular}




$$
-127-
$$

\begin{tabular}{lcccc} 
Silicate & -0.06 & -0.68 & -0.31 & -0.04 \\
Chlorophyll-a & -0.54 & -0.48 & -0.15 & 0.16 \\
EC & -0.34 & 0.20 & -0.72 & -0.42 \\
\% Total variation & $\mathbf{2 1 . 4 1}$ & $\mathbf{1 6 . 0 8}$ & $\mathbf{1 3 . 8 7}$ & $\mathbf{1 0 . 4 7}$ \\
\hline
\end{tabular}

Table 9. List of phytoplankton taxa included in the canonical correlation analysis of Ambata

\begin{tabular}{lccccc}
\hline & & & & & \\
Variables & Abbreviation & CV 1 & CV 2 & CV 3 & CV 4 \\
\hline Oscillatoria perornata & OP & $\mathbf{- 0 . 5 0}$ & 0.41 & 2.38 & $\mathbf{0 . 9 8}$ \\
Microcystis aeruginosa & MA & -0.27 & 0.43 & -0.34 & $\mathbf{- 0 . 4 4}$ \\
Merismopedium punctata & MP & -0.32 & -0.24 & 1.65 & 0.07 \\
Ankistrodesmus flactus & AF & -0.20 & $\mathbf{0 . 8 7}$ & -0.29 & 0.21 \\
Closterium gracile & CG & 0.08 & -0.04 & $\mathbf{0 . 5 4}$ & -0.20 \\
Amphiprora alata & AA & 0.43 & -0.07 & -0.49 & 0.16 \\
Amphora elliptica & AE & 0.07 & $\mathbf{0 . 9 6}$ & -0.14 & -0.28 \\
A. ovalis & AO & -0.07 & 0.54 & 0.09 & -0.48 \\
Chaetoceros tenuissimus & CT & $\mathbf{- 0 . 4 5}$ & -0.14 & $\mathbf{- 0 . 5 5}$ & 0.14 \\
Coscinodiscus marginatus & CM & -0.32 & 0.22 & 0.21 & 0.27 \\
Fragilaria crotonensis & FC & 0.22 & -0.14 & -0.07 & -0.32 \\
F. oceanica & FO & $\mathbf{- 0 . 5 3}$ & $\mathbf{- 0 . 8 9}$ & 0.09 & $\mathbf{- 0 . 6 6}$ \\
Gyrosigma acuminatum & GA & 0.10 & -0.03 & $\mathbf{0 . 5 8}$ & 0.11 \\
G. scalproides & GS & 3.34 & -1.05 & -0.32 & 0.47 \\
Leptocylindrus danicus & LD & -0.13 & $\mathbf{- 0 . 5 7}$ & $\mathbf{0 . 8 6}$ & $\mathbf{- 0 . 5 0}$ \\
Navicula cuspidata & NC & $\mathbf{- 0 . 5 5}$ & -0.49 & $\mathbf{- 0 . 4 9}$ & 0.01 \\
N. radiosa & NR & -0.04 & 0.16 & 0.33 & -0.08 \\
Nitzschia amphibia & NA & 0.27 & -0.23 & -0.11 & 0.13 \\
Thalassionema nitzschioides & TN & -0.26 & -0.20 & -0.07 & 0.02 \\
Pinnularia elongetum & PE & 0.20 & 0.07 & -0.13 & -0.46 \\
Surirella nervosa & SN & 0.33 & $\mathbf{0 . 8 1}$ & 0.12 & -0.18 \\
Peridinium & Pe & -0.64 & -0.38 & -0.43 & 0.10 \\
Ceratium & Ce & 0.10 & 0.11 & -0.09 & -0.19 \\
Gymnodium & Gy & 0.31 & $\mathbf{0 . 9 2}$ & $\mathbf{- 0 . 6 5}$ & -0.14 \\
\hline & & & & &
\end{tabular}

In the present study phytoplankton have shown a positive correlation with salinity value at all sampling stations because estuarine regions are subjected to considerable fluctuations and these micro floras were well adapted to such dynamic environment (Lionard et al., 2005). Phytoplankton need a wide variety of chemical elements with the critical ones being nitrogen and phosphorous (Dawes, 1981). In the present study it was registered that phytoplankton showed positive correlation with phosphate and inorganic nitrogenous nutrients but the relationship was not very significant. This could be due to lower concentration or rapid recycling of these nutrients. Similar positive correlation between phytoplankton and nitrogenous organic nutrients were observed by Steinhart et 
al. (2002) on southern Chilean lakes and Hergenrader (1980) in salt valley reservoirs (California). Dawes (1981) reported a negative relationship of phytoplankton with temperature and turbidity which supports our present observed results. Studies carried out by Ye and Cai (2011) suggested that the occurrence of Cyanophycean and Chlorophycean members were directly proportional to the concentration of dissolved inorganic nitrogen and phosphate which also corroborated with our studies.

Most of the species abundance were found to be correlated with environmental variables, and this might be due to cosmopolitan characteristic of the species indicating the species tolerance to a wide range in water quality (Bonilla et al., 2005). A negative correlation was observed for Cyanophycean members like Oscillatoria perornata and Merismopedium glauca with environmental variables like chlorophyll- $a$ and silicate. Most of the species belonging to Bacillariophyceae showed a positive correlation with environmental parameters like chlorophyll-a, silicate and phosphate. Chlorophycean members like Ankistrodesmus flactus, Closterium acerosum and Spirogyra indica showed a positive correlation with nitrate, DO and ammonia. Similar results were also obtained by Ye and Cai (2011) for their assessment on spring phytoplankton bloom of Xiangi Bay.

Navicula amphirhynclius and Navicula radiosa showed a positive correlation with $\mathrm{pH}$ and salinity which may have a major effect on its distribution. The close association of salinity and $\mathrm{pH}$ revealed the effect of tidal influence in the estuarine area. Temperature was found to have a positive relation with Clorella vulgaris and Merismopedium punctata. However, the negative correlation of temperature with ammonia and silicate showed the freshwater influence on these nutrients during postmonsoon season. Navicula cuspidate, Surirella nervosa, Thalassionema nitzschioides, Amphiprora alata, Amphora ovalis, Coscinodiscus marginatus and Amphora elliptica showed a positive correlation with chloroplyll- $a$, silicate and phosphate which indicates the significant role of these parameters in phytoplankton distribution (Harnstrom et al., 2009). Anaebena anomala, Nitzschia amphibian and Gymnodium sp. showed a negative correlation with inorganic nutrients, which showed their adaptability to a wide range of variations in physicochemical properties (Varis, 1991).

\section{Conclusion}

The present study summarizes the seasonal fluctuations of various physico-chemical parameters and plankton diversity in the coastal waters of the Narmada estuary as exploratory statistical data output. Freshwater discharges through the river and rivulets include additions of nitrate, phosphate and silicate to the coastal water mainly during the monsoon season (Martin et al., 2008). The addition of nitrogenous compounds and phosphorus compounds from anthropogenic sources such as fertilizer output, as an effect of industrialization and from agricultural runoff in the northern region of the Narmada estuary, has been observed during the monsoon in the water near the upper and middle reaches. Principal component analysis extracted two components (PC1 and PC2) responsible for the $76 \%$ variation observed in the estuary. The high load of nutrients like phosphate, nitrate and silicate during the monsoon contributes to the growth of phytoplankton community which is evident from the canonical correlation analysis. Hydrology and nutrients factors were found to be the main determining factors of phytoplankton distribution among the estuary (Costa et al., 2009). In the canonical correlation analysis the maximum correlation of phytoplankton with inorganic nutrients 
is linked to the abundance of these nutrients mostly entering during the monsoon season. The present study suggests that, hydrochemical variables play an important role in determining the phytoplankton distribution along estuarine gradient.

Acknowledgements. The authors are highly thankful to Ministry of Environment and Forest (MoEF), New Delhi for financial support.

\section{REFERENCE}

[1] Ahel, M., Barlow, R.G., Mantoura, R.F.C. (1996): Effect of salinity gradiant on the distribution of phytoplankton pigments in a stratified estuary. -Marine Ecology Progress Series 143: 289-295.

[2] APHA (American Public Health Association), AWWA (American Water Works Association), and WEF (Water Environment Federation). (1999): Standard methods for the examination of water and wastewater (20th ed.). Washington DC, USA.

[3] Ariyadej, C., Tansakul, R., Tansakul, P., Angsupanich, S. (2004): Phytoplankton diversity and its relationships to the physico-chemical environment in the Banglang reservoir, Yala province. -Songklanakarin Journal of Science and Technology 26: 595-607.

[4] Bally, R., McQuaid, C. D., Pierce, S. M. (1985): Primary productivity of the Bot river estuary, South Africa. -Transactions of the Royal Society of South Africa 45: 333-345.

[5] George,B., Nirmal Kumar, J.I, Kumar, N.K. (2012): Study on the influence of hydrochemical parameters on phytoplankton distribution along Tapi estuarine area of Gulf of Khambhat, India.- Egyptian Journal of Aquatic research 38: 157-170.

[6] Bonilla, S., Conde, D., Aubriot, L., Perez, M.D.C. (2005). Influence of hydrology on phytoplankton species composition and life strategies in a subtropical costal lagoon periodically connected with the Atlantic Ocean. -Estuaries 28: 884-895.

[7] Choudhury, A.K., Pal, R. (2010) Phytoplankton and nutrient dynamics dynamics of shallow coastal stations at Bay of Bengal, Eastern Indian Coast. -Aquatic Ecology 44: 5571.

[8] Clarke, K.R., Warwick, R.M. (2001). Changes in marine communities: an approach to statistical analysis and interpretation. 2nd edition, PRIMER- E: Plymouth.

[9] Costa, L.S., Huszar, V.L.M., Ovalle, A.R. (2009). Phytoplankton Functional Groups in a Tropical Estuary: Hydrological Control and Nutrient Limitation. -Estuaries and Coasts 32: $508-521$.

[10] Dawes, C.J. (1981). Marine Botany. A Wiley-Interscience publication, USA.

[11] Desikacharya. T.V.( 1959). Cyanophyta. Indian Council of Agricultural Research. New Delhi.

[12] DeJong T. M. (1975). A comparison of three diversity indices based on their components of richness and evenness. -Oikos 26: 222-227.

[13] Devassy, V.P., Goes, J.I. (1988). Phytoplankton community structure and sucession in a tropical estuarine complex (central west coast of India).-Estuarine, Coastal and Shelf Science 27: 671-685.

[14] Harnstrom, K., Karunasagar,I., Godhe. A. (2009). Phytoplankton species assemblage and their relationship to hydrographic factors- a study on the old port in Mangalore, Coastal Arabian Sea. -Indian Journal of Marine science 38: 224-234.

[15] Hergenrader, G. L. (1980). Eutrophication of the salt valley reservoirs, 1968-1973 II. Changes in physical and chemical parameters of eutrophication. -Hydrobiologia. 74: 225240.

[16] Lackey, J.B. (1938). The manipulation and counting of river plankton and changes in some organism due to formalin preservation. U.S. Public Health Reports. 63: 2080-2093. 
[17] Lionard, M., Muylaert, K., Gansbeke, D.V., Vyverman, W. (2005). Influence of changes in salinity and light intensity on growth of phytoplankton communities from the Schelde River and estuary (Belgium/The Netherlands). -Hydrobiologia 540: 105-115.

[18] Madhu, N.V., Joythibabu, R., Balachandran, K.K., Honey, U.K., Martin, G.D., Vijay, J.G., Shiyas, Guptha, G.V.M., Achuthankutty, C.T. (2007). Monsoonal impact on planktonic standing stock and abundance in a tropical estuary (Cochin backwatersINDIA). -Estuarine, Coastal and Shelf Science 73: 54-64.

[19] Maiti, S.K. (2003). Handbook of methods in Environmental Studies, Vol: 1, Water and Wastewater Analysis. (2nd ed.) Oxford Book Company, Jaipur, India.

[20] Martin, G.D., Vijay, J.G., Laluraj, C.M., Madhu, N.V., Joseph, T., Nair, M., Gupta, G.V.M., Balachandran K.K. (2008). Freshwater influence on nutrient stoichiometry in a tropical estuary, southwest coast of India. -Applied Ecology and Environmental Research 6: 57-64.

[21] Naik, S., Acharya, B.C., Mohapatra, A. (2009). Seasonal variations of phytoplankton in Mahanadi estuary, east coast of India. -Indian Journal of Marine science 38:184-190.

[22] Newall, E.J.R., Chu, V.T., Pringault, O., Amouroux, D., Arfi, R., Bettarel, Y., Bouvier, T., Got, P., Nguyen, T.M.H., Mari, X., Navarro, P., Duong, T.N., Cao, T.T.T., Pham, T.T., Ouillon, S., Torreton, J.P. (2011). Phytoplankton diversity and productivity in a high turbid, tropical coastal system (Bach Dang Estuary, Vietnam). Biogeosciences 8: 487-525.

[23] Newell G.E. ,Newell R.C. (1977). Marine Plankton, Hutchinson of London.

[24] Nirmal Kumar J.I., George, B., Kumar, R.N., Sajish P.R., Viyol, S. (2009). Assessment of spatial and temporal fluctuations in water quality of a tropical permanent estuarine system, Tapi, West Coast of India. -Applied Ecology and Environmental Research 7(3):267-276.

[25] Paerl, H.W., Lexia M. V., Alan R. J., Valerie W. (2007). Phytoplankton indicators of ecological change in the eutrophying Pamlico sound system, North Carolina. -Ecological Applications 17: 88-101.

[26] Palmer, M. (2006). Ordination methods an overview. http://ordination.okstate.edu/overview.htm.

[27] Panigrahi, S., Wikner, J., Panigrahy, R. C. Satapathy, K. K., Acharya, B. C. (2009). Variability of nutrients and phytoplankton biomass in a shallow brackish water ecosystem (Chilika Lagoon, India). Limnology 10: 73-85.

[28] Pradhan U.K., Shirodkar, P.V., Sahu, B.K. (2009). Physico-chemical characteristics of the coastal water off Devi estuary, Orissa and evaluation of its seasonal changes using chemometric techniques. Current Sciences 96: 1203-1209.

[29] Prandle, D. (2009). Estuaries: dynamics, mixing, sedimentation and morphology. Cambridge University Press, UK.

[30] Rantajarvi, E., Gran, V., Hallfors, S., Olsonen R. (1998). Effect of environmental factors on the phytoplankton community in the Gulf of Finland- unattended high frequency measurements and multivariate analyses. -Hydrobiologia 363: 127-139.

[31] Reingner,M. (2008). What is principal component analysis? Nature Biotechnology 26: 303-304.

[32] Satpathy, K. K., Mohanty, A. K., Natesan, U., Prasad, M. V. R., Sarkar. S. K. (2009). Seasonal variation in physicochemical properties of coastal waters of Kalpakkam, east coast of India with special emphasis on nutrients. -Environmental Monitoring and Assessment 164: 153-171.

[33] Shannon, C.E., Weiner, V. (1949). A mathematical Theory of Communication. University Press, Illinois Urban.

[34] Steinhart,G. S., Likens, G.E., Soto, D. (2002) Physiological indicators of nutrient deficiency in phytoplankton in southern Chilean lakes. -Hydrobiologia 489: 21-27.

[35] Strickland, S. C., Parsons, T. R. (1979). A Practical Handbook of Seawater Analyses, Bulletin of Fisheries Board of Canada, Ottawa.

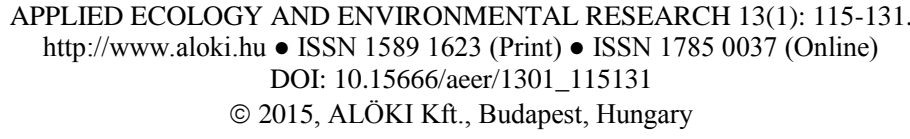


[36] Thomas, C.R. (1997). Identifying marine phytoplankton. Academic press, California.

[37] Varis, O. (1991). Association between Lake Phytoplankton community and growth factors- a canonical correlation analysis. -Hydrobiologia 210: 209-216.

[38] White,D.L., Porter, D.E., Lewitus, A.J. (2004). Spatial and temporal analyses of water quality and phytoplankton biomass in an urbanized versus a relatively pristine salt marsh estuary. -Journal of Experimental Marine Biology and Ecology 298: 255-273.

[39] Ye, L., Cai, Q. (2011). Spring phytoplankton blooms in Xiangxi Bay of three -gorges reservoir: spatiotemporal dynamics across sharp nutrient gradients. -Journal of Freshwater Ecology 26:11-18. 